\title{
China-Pakistan Economic Corridor Agreement: Impact on Shareholders of Pakistani Firms
}

\author{
WaQar I. Ghani ${ }^{1} \&$ Rajneesh Sharma ${ }^{1}$ \\ ${ }^{1}$ Haub School of Business, Saint Joseph's University, Philadelphia, PA, USA \\ Correspondence: WaQar I. Ghani, Haub School of Business, Saint Joseph's University, 5600 City Avenue, \\ Philadelphia, PA 19131, USA. Tel: 1-610-660-1661. E-mail: wghani@ @ju.edu
}

Received: November 12, 2017

Accepted: November 27, 2017 Online Published: December 10, 2017

doi:10.5539/ijef.v10n1p148

URL: https://doi.org/10.5539/ijef.v10n1p148

\begin{abstract}
This paper investigates the effects on shareholders' wealth of firms composed of the Karachi Stock Exchange 100 index, around events leading up to the signing of the China-Pakistan Economic Corridor (CPEC) agreement. We used standard event study methodology to measure the stock price reaction of KSE 100 Index (composed of all major sectors of Pakistan economy) around three key events related to CPEC agreement. Based on average security returns and cumulative average security returns, our results show significant and positive reaction of KSE 100 Index around all three key CPEC events. Our results capture market participants' assessment of the CPEC agreement's impact on future growth of Pakistani companies and the resultant effect of its shareholders' wealth. These positive wealth effects are of significant predictive value as additional bilateral and multilateral agreements are contemplated in that region. Our research contributes to a research stream that sees valuable payoffs of bilateral trade agreements for developing economies and support the argument that bilateral agreements can promote and attract institutional and private foreign direct investment (FDI), which otherwise may not be forthcoming. The argument goes on to argue that these bilateral agreements also help raise the quality of institutional framework in the developing countries.
\end{abstract}

Keywords: China-Pakistan economic corridor, bilateral agreements, one belt one road, shareholder value, bilateral agreement

\section{Introduction}

This paper investigates the effects on shareholders' wealth of firms composed of the Karachi Stock Exchange 100 index, around events leading up to the signing of the China-Pakistan Economic Corridor (CPEC) agreement. The purpose of testing the wealth effect of benchmark KSE 100 firms' index, around key events related to the CPEC agreement, is to capture the equity market's perception of the role that this historical agreement may play in the future economic growth of the Islamic Republic of Pakistan. In addition, the evidence of any wealth effects of the agreement on 100 firms that represent major sectors of the Pakistan economy is of great value to foreign and domestic investors and the signing parties as further bilateral and multilateral agreements including the "One Belt, One Road" (OBOR) initiative, are contemplated in the East, South and Central Asian hemisphere and beyond.

The CPEC agreement is an integral part of the multi-continent "One Belt, One Road" (OBOR) initiative, the People's Republic of China (PRC) has initiated, by signing US \$46 billion infrastructure development commitments with the Islamic Republic of Pakistan. The CPEC Agreement is based on 51 memoranda of understanding (MOUs) inked on April 20, 2015 during China's President Xi Jinping's visit to Pakistan. According to Wang Yi, China's foreign minister, "If 'One Belt, One Road' is like a symphony involving and benefiting every country, then construction of the China Pakistan Economic Corridor is the sweet melody of the symphony's first movement" (Shah, 2015).

The CPEC, a historical bilateral agreement, is composed of a network of ports, roads, rails (transport infrastructure), and pipelines (an investment of US \$12 billion) that link the Pakistani deep port city of Gwadar (on the shores of Arabian Sea), with China's city of Kashgar, in the western most region, Xinjiang Uighur Autonomous Region (XUAR). Towards that end, China is also building various energy projects based on nuclear, coal, wind, solar, and hydroelectric - a commitment of US \$34 billion to support the industrial infrastructure of Pakistan (Markey \& West, 2016). 
According to a financial analyst's research report, CPEC is a 'game changer' for both parties, especially for Pakistan. It is estimated that, both, due to direct and indirect impact of CPEC linked investments, Pakistan's GDP will grow to over 6 percent during the short and medium term as against a 2015-16 year growth rate of about 4 percent. In particular, sufficient and reliable energy supply will have a significantly positive effect on private investment activities (Naseem, 2015). Hence, further economic analysis of the CPEC agreement is warranted.

We used standard event study methodology to investigate the stock price reaction of KSE 100 Index (composed of all major sectors of Pakistan economy) around various events leading up to the signing of the CPEC agreement by China and Pakistan. Our test results based on average security returns and cumulative average security returns show significant positive reaction of KSE 100 Index around all selected key test events. In addition, for Event 1 (the Chinese Premier's visit to Pakistan to lay out the CPEC plan), the shareholders of KSE-100 companies experienced positive wealth effect in dollar terms, cumulative over three days $-2,-1,0$, to be roughly 1.87 billion dollars (4\%). Whereas, during Event 3 (the Chinese President's visit to Pakistan to sign the CPEC agreement), the positive wealth impact on KSE 100 firms' shareholders' wealth, cumulative over days $(-15,0)$ to be roughly 5.58 billion dollars $(8.25 \%)$.

These test results not only provide empirical evidence of the CPEC agreement's effect on shareholders' wealth but also capture the market participants' assessment of the direct and indirect impact that the CPEC agreement may have on the discounted presented value of all future cash flows of these companies. In addition, the evidence of positive wealth effects of the CPEC agreement is of immense predictive value to contracting parties as additional bilateral and multilateral agreements are evaluated. This research contributes to a body of economics literature that analyzes the stock market's response to various bilateral and multilateral trade agreements among nations across this hemisphere, in particular and across the globe, in general.

In the next section of this paper, we provide the background information and develop the testable hypotheses. Following that, we present the sample selection criteria and event study methodology. Next, we provide the empirical results, based on tests of various events. Finally, we present the discussion, conclusion and implications of the results we observed.

\section{Literature Review}

\subsection{Chinese "One Belt One Road (OBOR)" Vision}

It all began in the second century BC when caravans carrying goods on a trade route ran from the east of China (Chang'an, now Xian) to the west reaching in to the heart of the Roman Empire and the Mediterranean. These interactions, across a network of trading routes, not only touched along the way the economies but also the cultures of Chinese, Indian, Persian, Arab, Roman and Greek communities. At various times, over the centuries, the trading activity experienced its highs and lows. Much later, in 1887, this route was given the name the Silk Road by a German geographer, Ferdinand von Richthofen, because silk was the main and prized product that the merchants carried on this network of roads.

In the currently evolving geo-political, tactical and strategic realignments, China suddenly has a bigger gap to fill created by the Trump administration's policy of 'America First' by backing out of the Trans-Pacific Agreement. Chinese President Xi Jinping's attempt to link back to and revive the richness and glory of the Silk Road era provides precisely one of the many opportunities that would accrue. This vision of linking more than 60 countries through massive investments in various infrastructure projects across Asia, Europe, and Africa is slowly taking shape in the form of OBOR, which China calls "One Belt, One Road" (The Economist, 2016).

According to The Economist (2016), there are 900 OBOR deals in the works totaling $\$ 890$ billion. Examples of projects include linking by a high-speed rail network the port city of Piraeus, Greece, to a Hungarian city, laying a gas pipeline from the Bay of Bengal passing through Myanmar and ending in south-west China, and linking Beijing and Duisburg, Germany through rail. China intends to commit a cumulative amount of $\$ 4$ trillion in OBOR countries. Toward that end, Chinese President Xi Jinping, in October 2013, proposed the idea of an Asian Infrastructure Investment Bank (AIIB), similar to the World Bank. The Bank has an initial capital of 100 billion with roughly 30 percent contributed by China. According to AIIB's official website:

The AIIB, a modern knowledge-based institution, will focus on the development of infrastructure and other productive sectors in Asia, including energy and power, transportation and telecommunications, rural infrastructure and agriculture development, water supply and sanitation, environmental protection, urban development and logistics, etc. ... AIIB welcomes all regional and non-regional countries, developing and developed countries, that seek to contribute to Asian infrastructure development and regional connectivity ... Representatives from the 57 PFMs [Prospective Founding Members] gathered on 
June 29, 2015 in Beijing at a Signing Ceremony of the Bank's Articles of Agreement at the Great Hall of the People and 50 PFMs signed the Articles ...

\subsection{China-Pakistan Economic Corridor (CPEC) Agreement - A Historical Perspective}

Pakistan and China are 'all-weather friends' and this friendship goes back to 1950, when newly independent Pakistan formally recognized China. They share a 523 kilometer northern border that, on the northwest links Afghanistan and on the east, India. All these years, Pakistan has primarily relied on China for political, economic and military assistance. According to Small, 2015, in this historical journey, "China has been Pakistan's diplomatic protector, its chief arms supplier, and its call of last resort when every other supposed friend has left it in the lurch."

Pakistan's contribution in this strategic relationship has not been any less significant. Back in 1971, Pakistan was the facilitator in a secret trip that then US Secretary of State Henry Kissinger took to China, that in turn, led to the historical visit in 1972 of President Richard Nixon to Beijing. Pakistan also extended its assistance to China after the 1989 Tiananmen Square crackdown. It has lent its support to China to transition from its current status of an observer to a member of South Asian Association for Regional Cooperation (SAARC) (Vandewalle, 2015).

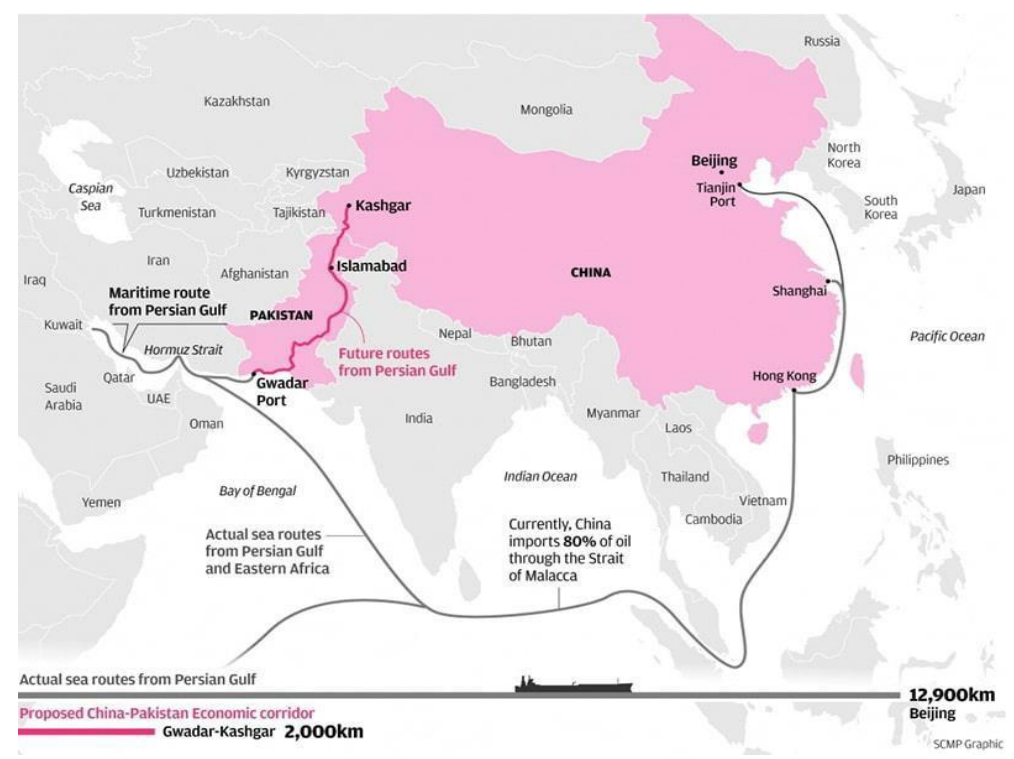

Figure 1. Proposed China-Pakistan economic corridor

Source: Deloitte Study: Pakistan Economic Survey 2014-15.

As for China, Pakistan has emerged as an integral part of its strategic global OBOR vision. As shown in Figure 1 above, currently, eighty percent of China's oil imports from the Persian Gulf pass through the Straits of Malacca before reaching its eastern shores, a distance of $12900 \mathrm{~km}$. China, rightly so, views the Straits of Malacca, sea route, as highly vulnerable (a choke point) during any hostility. Conversely, Kashghar, Xinjiang Province, in the west of China, is $4376 \mathrm{~km}$ from Beijing. The province's population is composed of two Muslim ethnic majority groups, Uighur and Hui. The proposed trade route from the deep sea Port of Gwadar to Kashghar, is $2000 \mathrm{~km}$ and the Port of Gwadar to the Straits of Hormuz is $400 \mathrm{~km}$. This strategic rerouting of oil supply will cut the existing shipping time for China from 45 days to only 10 days. In addition, for the landlocked countries of central Asia, it would provide a viable access to the Arabian Sea (Ebrahim, 2015).

\subsection{CPEC and China-Pakistan Bilateral Trade Relationships}

Back in January 1963, China and Pakistan inked the first set of commercial links by signing a long-term bilateral trade agreement. Since then, both countries have strengthened these economic and commercial relationships. Subsequently, both countries signed successive Free Trade Agreements (FTA), the first on November 24, 2006 for getting access to markets for various export products and later in February 21, 2009, another FTA for services trade (Ministry of Finance, 2014:126). According to recently reported statistics, the volume of trade between China and Pakistan has risen to roughly $\$ 20$ billion in 2015. This translates in to a growth of $\$ 5.7 \mathrm{bn}$ in year 2000 to $\$ 100.11$ bn in year 2015 (Dawn, 2016).

As for Pakistan, the China-Pakistan Economic Corridor (CPEC) agreement worth US \$46 billion (operationalized 
in three phases: early harvest; medium term; long-term, with an estimated overall project outlay of US $\$ 75$ billion) with a completion date of year 2030, would not only cement this historical bond but would also take the two nations' strategic relationship to an entirely new and higher level of economic, political, and military alliance that, if successfully implemented, could potentially have far reaching geopolitical consequences for all stakeholders who have deep interests in this region of the globe.

\section{Hypothesis Development}

\subsection{Bilateral Trade Agreement}

In many developing countries, foreign investors face multiple institutional risks (legal, political, etc.) to their capital in host countries. Under the bilateral trade agreements, foreign investors receive greater protection and security not generally available to domestic businesses (Vandevelde, 1998). This in turn helps developing countries promote and attract foreign direct investment (FDI), a private source of international financial capital, which otherwise may not be forthcoming. Indirectly, these bilateral agreements also help raise the quality of the institutional framework in the developing countries (Elkins et al., 2004). The CPEC agreement can be framed in the same context when evaluating its beneficial effects on the future economic growth of Pakistan.

\subsection{Stock Market Reaction of CPEC Related Events}

According to Scheraga and Calfee (1996), the equity market, through its stock price behavior, unambiguously signals the expected costs and benefits of a value relevant event. Ghani and Haverty (1998) examined the impact of the passage of the General Agreement on Trade and Tariff (GATT) and Ghani and Haverty (1995) examined the effect of the passage of the North American Free Trade Agreement (NAFTA) on the share prices of U.S. public companies and found significant market reaction around the test dates. We hypothesize that the CPEC related events significantly increase the present value of future cash flows of KSE 100 firms. Hence, our tests are expected to show significantly positive stock price reaction around CPEC related events.

Figure 2 provides an overview of the infrastructure projects. According to some estimates, the values of CPEC projects are estimated to be greater than all the foreign direct investment inflows in to Pakistan since 1970. In other words, the value of these projects will be equal to $17 \%$ of gross domestic product of Pakistan for 2015 . This in turn, according to some estimates, would create roughly 700000 jobs between the years 2015-2030 (The Pakistan Times, 2016).

Pakistan's Karachi Stock Exchange 100 (KSE 100 Index) has again been included in the emerging markets' equity index of the MSCI (Morgan Stanley Capital Index). Pakistan's Karachi Stock Exchange, since 1994, was a part of the EM Index but its membership was cancelled in 2008 because of liquidity issues. Later in 2009, Pakistan was made a part of the MSCI's Frontier Markets Index.

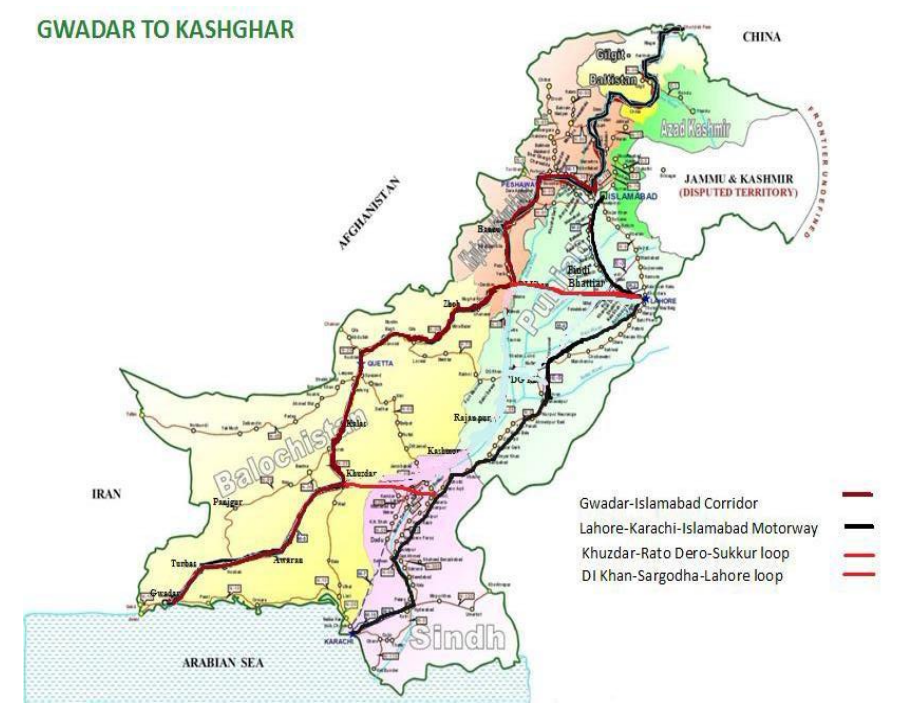

Figure 2. CPEC infrastructure projects

Source: Deloitte Study: Pakistan Economic Survey 2014-15.

The equity analysts, (who follow various sectors of the Pakistan economy for their retail, institutional and foreign clients) in their research report forecast that CPEC energy investment projects upon completion would 
lead to cheap, reliable, and sufficient energy supply for various sectors of the economy. They expect that this in turn would lead to a significant increase in the sales and earnings of various sectors of the economy, in particular, the steel and cement sectors. Other sectors will also immensely benefit from the improved business environment. For example, cheap and abundant energy would increase production and the sales of the manufacturing sector, improve margins, accelerate income growth, and trigger new capital spending. Similarly, the financial sector will be more confident in lending to various sectors including the consumer sector. A rise in income of consumers, in turn will trigger higher demand for various products and services leading to a higher level of growth in GNP. And, these CPEC driven economic growth expectations will significantly increase the present value of future cash flows of beneficiary firms, in turn significantly increasing the share price of these firms (Naseem, 2015).

Table 1. List of test events*

\begin{tabular}{lll}
\hline Event & Date & Event \\
\hline 1 & May 22, 2013 & Chinese Premier's Visit \\
2 & July 3, 2013 & Nawaz Sharif Visits China \\
3 & April 20, 2015 & CPEC Agreement Signed \\
\hline
\end{tabular}

\section{Event 1: Chinese Premier's Visit to Pakistan to Formally Sign Agreements related to Gwadar}

We selected event 1 (May 22, 2013) to be when the Chinese Premier arrived on an official State visit to Pakistan. One purpose of this visit was to affirm the formal establishment of the economic corridor linking the Port of Gwadar (that China took possession of back in February, 2013) to Kashgar, China. This culminated in the signing of 11 agreements of "cooperation in political, economic, maritime, aerospace, energy, transportation and cultural fields" (Ministry of Foreign Affairs, 2013).

Since these agreements laid the foundation for furthering the operationalization of CPEC, we expect the average security returns (AR) and cumulative abnormal returns (CAR) to be positive. Thus, the hypotheses H1a and H1b are as follows:

H1a: Chinese Prime Minister's visit to Pakistan to formalize Economic Corridor had a positive effect on the average security returns (AR) of KSE 100 Firms' Index.

H1b: Chinese Prime Minister's visit to Pakistan to formalize Economic Corridor had a positive effect on the average cumulative security returns (CAR) of KSE 100 Firms' Index.

\section{Event 2: Prime Minister, Nawaz Sharif's Visit to China related to Economic Corridor}

The prime minister of Pakistan, Mian Nawaz Sharif, visited China on July 3, 2013 to affirm Pakistan's commitment to CPEC. We identified this event to be value relevant and treated it as event 2 . The purpose of Mr. Sharif's visit was to affirm eight economic corridor agreements (valued at $\$ 18$ billion), linking Kashgar (China) to Gwadar port (Pakistan), signed earlier in May during the Chinese Premier's visit to Islamabad. In view of above event's value to market participants, the following hypotheses $\mathrm{H} 3 \mathrm{a}$ and $\mathrm{H} 3 \mathrm{~b}$ are formulated:

H2a: Pakistan's Prime Minister's visit to China to formalize economic corridor agreements had a positive effect on the average security returns (AR) of KSE 100 Firms' Index.

H2b: Pakistan's Prime Minister's visit to China to reaffirm economic corridor agreements had a positive effect on the average cumulative security returns (CAR) of KSE 100 Firms' Index.

Event 3: April 20, 2015- CPEC Agreement Signed between China \& Pakistan; the signatories are President Xi Jinping of China and Premier Nawaz Sharif of Pakistan

We designate Event 3 to be the one when President Xi Peng visits Pakistan to sign the CPEC Agreement on April 20, 2015. According to Dawn News (2015), "Mr. Xi Jinping's visit is being dubbed as a 'fate-changing visit' as he is expected to roll out nearly $\$ 28$ billion for the first phase of the $\$ 45 \mathrm{bn}$ flagship Pakistan-China Economic Corridor (PCEC) Project." In his speech, on this occasion, President Xi Jinping stated that "Of all the cooperation documents that Prime Minister Sharif and I signed or witnessed the signing of, more than 30 of them concern the corridor." He went on to add, "They include the facilities of the Gwadar port, the second phase of the upgrading project for the Karakoram highway, the motorway project between Karachi and Lahore, the rail transportation Orange line project of Lahore, and other major transportation infrastructure projects and a series of energy projects."

Thus, we feel that China's President's visit cemented CPEC into an operational agreement that would have a significant positive impact on the cash flows of large Pakistani firms. This in turn leads us to form the following 
hypotheses:

H3a: China's President's formal visit to Pakistan to sign the CPEC Agreement had a positive effect on the average security returns (AR) of KSE 100 Firms' Index.

H3b: China's President's formal visit to Pakistan to sign the CPEC Agreement had a positive effect on the average cumulative security returns (CAR) of KSE 100 Firms' Index.

\section{Research Design}

We analyze the stock market reaction to the three events surrounding the CPEC agreement as reported earlier in Table 1. Each particular event date is treated as the Event Day 0 in our event-study model.

We use the Karachi Stock Exchange 100 index (KSE 100) as a proxy for Pakistan's stock markets. Factset (n.d) describes the Index, "KSE began with a 50 shares index. As the market grew a representative index was needed. On November 1, 1991, the KSE-100 was introduced and remains to this date the most generally accepted measure of the Exchange. The KSE-100 is a capital weighted index and consists of 100 companies representing about 90 percent of market capitalization of the Exchange."

We view the KSE 100 Index to be the most reliable proxy that captures all key business fundamentals of publicly traded companies in Pakistan. Thus, we extracted "KSE 100 Index (Ticker number: KSE 100-KAR; name in Pakistan is KSE 100)" levels from Factset Prices. We use USD denominated levels for KSE 100.

We use the S\&P Emerging Markets index as a proxy for the overall market portfolio. We feel that methodologically, using an Emerging Market index is an appropriate benchmark to test against variation in KSE-100 index instead of employing a developed market index. We obtain the dollar denominated "S\&P Emerging Market BMI (Broad Market Index) Prices" from Factset. The S\&P Emerging Markets index is coded as SBBREM in Factset. We match the trading dates of the KSE 100 and the S\&P emerging market index. There are some days where we have an observation for the S\&P index, however Pakistani markets are closed. Therefore, we construct returns on the KSE and Emerging market index only on the trading days when Pakistani markets are open.

Standard event study methodology models the returns of individual securities as a function of market portfolio. A pre-event period is used to estimate the model parameters. These estimates are then used to predict the expected returns for any individual security. The differences between predicted and actual returns are the abnormal returns. The abnormal returns are attributed to the event in question. Further, cumulative abnormal returns are calculated as the sum of abnormal returns over the event window.

In our model, we use KSE 100 returns (USD denominated) as the returns on the individual securities. The returns for any day $i$ are calculated by taking the natural logarithm of ratio of the index level from day $i$ to index level on day $i-1$. Specifically,

$$
r_{i}=\ln \left(p_{i} / p_{i-1}\right)
$$

where $\mathrm{P}_{\mathrm{i}}$ is the price on day $i$ and $\mathrm{P}_{\mathrm{i}-1}$ is the price on day $i-1$. Similarly, we calculate the returns for the S\&P Emerging market index for each day $i$. We use the market model for our event study. The KSE 100 return is the dependent variable and the Emerging Market returns are the explanatory variables. Specifically, we use the following model where $r_{i K S E}$ is the return on KSE index on day $i$, and $r_{i S B B R E M}$ is the return on S\&P emerging market index on day $i$.

$$
r_{i K S E}=\alpha+b r_{i S B B R E M}+\varepsilon_{i t}
$$

We estimate the model by using data starting at 150 trading days before the event and going to 30 trading days before the event. Thus, the estimation period is -150 to -30 trading days. We use the $\mathrm{S} \& \mathrm{P}$ emerging market index returns of a specific day (the explanatory variable) and the estimated values of $\alpha$ and $\beta$ to predict the expected returns for KSE 100 index. These expected returns are subtracted from actual returns to generate abnormal returns. Hence, the difference between the actual and predicted values of the KSE 100 return on a specific day is the abnormal return for that day.

We report the abnormal returns starting from 15 trading days prior to the event through 15 trading days after the event. An examination of trading prior and subsequent to the event date is warranted in order to detect the effects of information leakage and dissemination, respectively. For brevity, we report abnormal returns from 5 days prior to 5 days after the event.

To capture the aggregate effect of specific events, we calculate cumulative abnormal returns by adding the abnormal returns of multiple days. The cumulative abnormal returns are calculated as the sum of the daily abnormal returns during the selected event window. Specifically, $C A R_{(j, k)}$ equals 


$$
\operatorname{CAR}_{(j, k)}=\sum_{i=j}^{j} A R_{i}
$$

For robustness, we calculate the cumulative abnormal returns for various selective event windows. These selective intervals that we examine are $(-15,+15),(-10,+10),(-5,+5),(-2,+2),(-1,+1),(-15,0),(-10,0),(-5,0)$, $(-2,0),(-1,0),(0,+1),(0,+5),(0,+10),(0,+15)$.

\section{Results}

\subsection{Abnormal Returns Test: Wealth Effects- Event 1 (Chinese Premier's Visit to Pakistan to Lay Out the CPEC Plan)}

As shown in Table 2, Panel A and Panel B, report the test results of Event 1, May 22, 2013 - the date on which the Chinese Premier visited Pakistan to lay out the CPEC Plan. We test the behavior of the average daily abnormal returns (AR) around the -5 to +5 trading intervals (Panel A) and cumulative abnormal returns (CAR) around the same test events (Panel B) for trading intervals -15 to +15 , in relation to a selected event day $(t=0)$. The Patell Z-statistic is used to test whether the change in abnormal returns and cumulative abnormal returns around the event date are significantly different from zero.

Table 2, Panel B, reports the cumulative average abnormal returns (CAR) percentages. There are two methodological reasons behind analyzing CAR: one, to measure any significant reassessment in investors' expectation associated with market moving information leaked days before the event date; two, to assess the sensitivity of the test results related to any potential measurement error while identifying the exact timing of the event. As hypothesized in $\mathrm{H} 1 \mathrm{a}$ and $\mathrm{H} 1 \mathrm{~b}$, we expect positive abnormal returns behavior around this event. As shown in Table 2, the average abnormal returns of the firms on day 0 are positive and statistically significant at roughly 5 percent level, with a Patell Z-value of 1.616. Results suggest that the event was anticipated; both day -2 and day -1 are highly significant at the .05 level or better.

As shown in Table 2, Panel B, the KSE-100 index reacts highly significantly and positively once abnormal returns are cumulated (CAR) over selective $(-10,0),(-5,0),(-2,0),(-1,0)$ trading intervals leading up to the test day 0 ; for example, the CARs for trading interval $(-10,0)$ increase by 9.44 percent (Patell $\mathrm{Z}=3.74$ ), and are highly significant at the 1 percent level. These results suggest that investors expected the CPEC plan presented by the Chinese Premier in Islamabad, Pakistan, to have a very positive impact on future cash flows of the KSE-100 index firms.

Table 2. CPEC Event 1: May 22, 2013-Chinese Premier's visit to Pakistan to lay out the CPEC plan

\begin{tabular}{cccc}
\hline Panel A. Table contains the abnormal returns for KSE 100 surrounding test event 1 & P Value \\
\hline Event Day & AR\% & Patell Z & 0.3275 \\
$\mathbf{- 5}$ & $0.34 \%$ & 0.447 & 0.1296 \\
$\mathbf{- 4}$ & $-0.86 \%$ & -1.128 & 0.2519 \\
$\mathbf{- 3}$ & $0.51 \%$ & 0.669 & 0.0429 \\
$\mathbf{- 2}$ & $1.30 \% * *$ & 1.718 & 0.0262 \\
$\mathbf{- 1}$ & $1.47 \% * *$ & 1.941 & 0.0530 \\
$\mathbf{0}$ & $1.23 \% *$ & 1.616 & 0.2229 \\
$\mathbf{1}$ & $-0.61 \%$ & -0.762 & 0.3736 \\
$\mathbf{2}$ & $-0.24 \%$ & -0.322 & 0.0082 \\
$\mathbf{3}$ & $-1.82 \% * * *$ & -2.401 & 0.0008 \\
$\mathbf{4}$ & $2.39 \% * * * *$ & 3.147 & 0.3346 \\
$\mathbf{5}$ & $-0.33 \%$ & -0.427 & P Value \\
\hline Panel B: Table contains the Cumulative Abnormal Returns for KSE 100 surrounding test event 1 & 0.0008 \\
Event Window & CAR\% & Patell Z & 0.0001 \\
$(-15,+15)$ & $13.43 \% * * * *$ & 3.177 & 0.0007 \\
$(-15,0)$ & $11.31 \% * * * *$ & 3.715 & $<0.0001$ \\
$(-10,+10)$ & $11.15 \% * * * *$ & 3.205 & 0.0876 \\
$(-10,0)$ & $9.44 \% * * * *$ & 3.740 & 0.0159 \\
$(-5,+5)$ & $3.38 \% * *$ & 1.356 & 0.0305 \\
$(-5,0)$ & $3.99 \% * * *$ & 2.148 & 0.0012 \\
$(-2,+2)$ & $3.15 \% * *$ & 1.874 & 0.0533 \\
$(-2,0)$ & $4.00 \% * * * *$ & 3.045 & 0.0060 \\
$(-1,+1)$ & $2.09 \% *$ & 1.613 & 0.2730 \\
$(-1,0)$ & $2.70 \% * * *$ & 2.515 & 0.3643 \\
$(0,+1)$ & $0.62 \%$ & 0.604 &
\end{tabular}




\begin{tabular}{cccc}
\hline$(0,+10)$ & $2.94 \%$ & 1.176 & 0.1199 \\
$(0,+15)$ & $3.35 \%$ & 1.110 & 0.1335 \\
\hline
\end{tabular}

Note. $* * * *, * * *, * * *$ Representing Significance at $0.001,0.01,0.05$, and 0.10 levels, based on Patell Z-Statistics.

In the above table, the first column shows day 0 as the event-date around which abnormal returns (ARs) are calculated based on various trading days and is shown in the second column, along with Patell Z-statistics with the associated p-values in the subsequent two columns. Data Source: FactSet Research Systems. (n.d.). Pakistan KSE 100 Shares description. Retrieved April 4, 2017, from FactSet database.

\subsection{Abnormal Returns Test: Wealth Effects - Event 3 (July 3, 2013-Pakistan Premier Nawaz Sharif Visits China)}

Table 3, Panel A and Panel B report the test results of Event 2, July 3, 2013: the date on which Pakistan's Premier visited China to further strengthen and formalize the CPEC Plan. The value impact of Event 2 is examined by calculating the average daily abnormal returns (AR) and cumulative average abnormal returns (CAR) percentages. As hypothesized in $\mathrm{H} 2 \mathrm{a}$ and $\mathrm{H} 2 \mathrm{~b}$, we expect positive abnormal returns behavior around this event. As reported in Table 3, the average abnormal returns of the firms on day 0 are positive but statistically insignificant. Results suggest that the expectations were already priced in the market three weeks ago back when the Chinese Premier visited Pakistan. We also employed CARs to test leakage around various trading intervals related to this event.

As shown in Table 3, Panel B, the KSE-100 index reacts highly significantly and positively once abnormal returns are cumulated over selective $(-5,+5),(-2,+2)$, and $(-2,0)$ trading intervals; for example, the CARs for trading interval $(-2,+2)$ increase by 4.08 percent $($ Patell $\mathrm{Z}=2.219)$, and are highly significant at roughly the 1 percent level. These results indicate that investors expected the CPEC plan to further evolve and strengthen due to the Pakistan Premier's return visit to China.

Table 3. CPEC Event 2: July 3, 2013- Pakistan Premier Nawaz Sharif visits China

\begin{tabular}{|c|c|c|c|}
\hline \multicolumn{4}{|c|}{ Panel A: Table contains the Abnormal Returns for KSE 100 surrounding test event 2} \\
\hline Event Day & $\mathrm{AR} \%$ & Patell Z & P Value \\
\hline-5 & $-0.78 \% * *$ & -0.918 & 0.1794 \\
\hline-4 & $-0.23 \%$ & -0.282 & 0.3890 \\
\hline-3 & $-0.91 \%$ & -1.075 & 0.1411 \\
\hline-2 & $1.48 \%$ & 1.827 & 0.0339 \\
\hline-1 & $0.97 \%$ & 1.179 & 0.1192 \\
\hline 0 & $0.42 \%$ & 0.493 & 0.3112 \\
\hline 1 & $0.50 \%$ & 0.608 & 0.2715 \\
\hline 2 & $0.70 \%$ & 0.856 & 0.1959 \\
\hline 3 & $0.69 \%$ & 0.841 & 0.2003 \\
\hline 4 & $1.39 \% * *$ & 1.703 & 0.0443 \\
\hline 5 & $0.90 \%$ & 1.103 & 0.1349 \\
\hline \multicolumn{4}{|c|}{ Panel B: Table contains the Abnormal Returns for KSE 100 surrounding test event 2} \\
\hline Event Window & $\mathrm{CAR} \%$ & Patell Z & P Value \\
\hline$(-15,+15)$ & $-1.36 \%$ & -0.219 & 0.4134 \\
\hline$(-15,0)$ & $-6.11 \% * *$ & -1.784 & 0.0372 \\
\hline$(-10,+10)$ & $-1.09 \%$ & -0.189 & 0.4250 \\
\hline$(-10,0)$ & $-3.72 \%$ & -1.263 & 0.1034 \\
\hline$(-5,+5)$ & $5.13 \% * *$ & 1.910 & 0.0281 \\
\hline$(-5,0)$ & $0.96 \%$ & 0.499 & 0.3088 \\
\hline$(-2,+2)$ & $4.08 \% * * *$ & 2.219 & 0.0132 \\
\hline$(-2,0)$ & $2.88 \% * *$ & 2.020 & 0.0217 \\
\hline$(-1,+1)$ & $1.89 \% *$ & 1.316 & 0.0940 \\
\hline$(-1,0)$ & $1.39 \% * *$ & 1.182 & 0.1186 \\
\hline$(0,+1)$ & $0.92 \%$ & 0.778 & 0.2182 \\
\hline$(0,+5)$ & $4.60 \%$ **** & 2.288 & 0.0111 \\
\hline$(0,+10)$ & $3.05 \%$ & 1.150 & 0.1251 \\
\hline$(0,+15)$ & $5.17 \% *$ & 1.603 & 0.0545 \\
\hline
\end{tabular}

Note. $* * * * * * *, * * *$ Representing Significance at $0.001,0.01,0.05$, and 0.10 levels, based on Patell Z-Statistics.

In the above table, the first column shows day 0 as the event-date around which abnormal returns (ARs) are calculated based on various trading days and is shown in the second column, along with Patell $\mathrm{Z}$ statistics with the associated $\mathrm{p}$-values in the subsequent two columns. Data Source: FactSet Research Systems. (n.d.). Pakistan KSE 100 Shares description. Retrieved April 4, 2017, from FactSet database. 


\subsection{Abnormal Returns Test: Wealth Effects - Event 3 (April 20, 2015 - CPEC Agreement Signed between China \& Pakistan}

Table 4, Panel A and Panel B show the test results of Event 3 (April 20, 2015), the date on which China's President visited Pakistan to sign the CPEC agreement. The value impact of Event 3 is examined by calculating the average daily abnormal returns (AR) and cumulative average abnormal returns (CAR) percentages. As hypothesized in $\mathrm{H} 3 \mathrm{a}$ and $\mathrm{H} 3 \mathrm{~b}$, we expect positive abnormal returns behavior around this event. As reported in Table 4, the average abnormal returns of the firms on day 0 are positive but statistically insignificant; whereas, the abnormal returns on day -1 and day -2 , are positive (1.36\% and $1.52 \%$, respectively) and highly significant at the 5 percent level or better. Results suggest that the Chinese President's visit and the signing of the CPEC agreement were highly anticipated by the investors and were priced in the market a couple of trading days before the test event. We also employed CARs to test leakage around various trading intervals related to this event.

Table 4, Panel B, shows that the KSE-100 index reacts highly significantly and positively once abnormal returns are cumulated over the past trading 15 days $(-15,0)$ or $(-2,0)$; for example, the CARs for trading interval $(-15,0)$ increase by 8.25 percent (Patell $Z=3.070$ ), and are highly significant at 1 percent level ( $\mathrm{p}$-value $=0.0011$ ). These results suggest that vital information related to the CPEC agreement that included an unprecedented commitment by China of billions of dollars for CPEC projects was leaked to the market leading up to the signing of the agreement.

\subsection{Wealth Effect in Dollars}

We also calculated the wealth impact in dollars for selected events. For Event 1 (the Chinese Premier's visit to Pakistan to lay out the CPEC plan) the shareholders of KSE-100 companies experienced an overall positive wealth effect, in dollar terms, cumulative over three days $-2,-1,0$, which was roughly 1.87 billion dollars (4\%). Whereas, during Event 3 (the Chinese President's visit to Pakistan to sign the CPEC agreement), the positive wealth impact on shareholders' wealth, cumulative over days $(-15,0)$ was roughly 5.58 billion dollars $(8.25 \%)$.

Table 4. CPEC Event 3: April 20, 2015- CPEC agreement signed between China and Pakistan; the signatories are President Xi Ping of China and Premier Nawaz Sharif of Pakistan

\begin{tabular}{|c|c|c|c|}
\hline Event Day & $\mathrm{AR} \%$ & Patell Z & P Value \\
\hline-5 & $-0.53 \%$ & -0.791 & 0.2144 \\
\hline-4 & $-0.30 \%$ & -0.453 & 0.3252 \\
\hline-3 & $0.36 \%$ & 0.540 & 0.2946 \\
\hline-2 & $1.36 \% * *$ & 2.013 & 0.0221 \\
\hline-1 & $1.52 \% * * *$ & 2.251 & 0.0122 \\
\hline 0 & $0.26 \%$ & 0.381 & 0.3517 \\
\hline 1 & $-1.11 \% *$ & -1.642 & 0.0503 \\
\hline 2 & $1.22 \% * *$ & 1.822 & 0.0343 \\
\hline 3 & $-0.30 \%$ & -0.448 & 0.3271 \\
\hline 4 & $0.74 \%$ & 1.104 & 0.1348 \\
\hline 5 & $-0.23 \%$ & -0.349 & 0.3636 \\
\hline \multicolumn{4}{|c|}{ Panel B: Table contains the Cumulative Abnormal Returns (CARs) for KSE 100 surrounding test event 3} \\
\hline Event Window & CAR\% & Patell Z & P Value \\
\hline$(-15,+15)$ & $5.48 \% *$ & 1.464 & 0.0715 \\
\hline$(-15,0)$ & $8.25 \% * * * *$ & 3.070 & 0.0011 \\
\hline$(-10,+10)$ & $3.69 \%$ & 1.188 & 0.1175 \\
\hline$(-10,0)$ & $4.56 \% * *$ & 2.033 & 0.0210 \\
\hline$(-5,+5)$ & $2.98 \% *$ & 1.335 & 0.0910 \\
\hline$(-5,0)$ & $2.66 \% *$ & 1.609 & 0.0539 \\
\hline$(-2,+2)$ & $3.25 \%$ *** & 2.157 & 0.0155 \\
\hline$(-2,0)$ & $3.13 \% * * *$ & 2.682 & 0.0037 \\
\hline$(-1,+1)$ & $0.67 \%$ & 0.571 & 0.2839 \\
\hline$(-1,0)$ & $1.77 \%$ ** & 1.861 & 0.0314 \\
\hline$(0,+1)$ & $-0.85 \%$ & -0.892 & 0.1862 \\
\hline$(0,+5)$ & $0.58 \%$ & 0.354 & 0.3616 \\
\hline$(0,+10)$ & $-0.61 \%$ & -0.277 & 0.3908 \\
\hline$(0,+15)$ & $-2.51 \%$ & -0.937 & 0.1745 \\
\hline
\end{tabular}

Note. ****, ***, **, * Representing Significance at 0.001, 0.01, 0.05, and 0.10 levels, based on Patell Z-Statistics.

In the above table, the first column shows day 0 as the event-date around which abnormal returns (ARs) are calculated based on various trading days and is shown in the second column, along with Patell Z-statistics with the associated p-values in the subsequent two columns. Data Source: FactSet Research Systems. (n.d.). Pakistan KSE 100 Shares description. Retrieved April 4, 2017, from FactSet database. 


\section{Conclusion}

This study investigates the effects on shareholders' wealth of firms composed of the Karachi Stock Exchange 100 index, around events leading up to the signing of the China-Pakistan Economics Corridor (CPEC) agreement. The purpose of testing the wealth effect of benchmark KSE 100 firms' index (using standard event study methodology) around key events related to the CPEC agreement is to capture the equity market's perception of the role that this historical agreement may play in the future economic growth of the Islamic Republic of Pakistan. The evidence of positive wealth effects of the agreement on 100 firms that represent major sectors of the country is of significant value to the signing parties as additional bilateral and multilateral agreements are contemplated.

We identified three key CPEC-related events to test our hypotheses. These events were: Event $1-$ The Chinese Premier visits Pakistan and lays out CPEC plan; Event 2 - Nawaz Sharif, Pakistani Prime Minister, visits China to strengthen the idea; Event 3 - The Chinese President visits Pakistan and signs the CPEC agreement. Our test results, using abnormal returns (AR) and cumulative abnormal returns (CARs) measures, show positive and statistically significant wealth effects around all three key events. More importantly, Event 1 (when the Chinese Premier visits Pakistan to lay out the CPEC plan) and Event 3 (when the Chinese President visits Pakistan and signs the CPEC agreement) are highly significant on day 0 or a few days before day 0 .

Our test results suggest that shareholders of Pakistani companies, that form the KSE-100 Index, are expected to experience significant increases in the present value of future cash flows resulting in higher present values due to CPEC agreement-related impact on energy, transportation, industrial and financial sectors of Pakistan's economy. For example, for Event 1 (the Chinese Premier's visit to Pakistan to lay out the CPEC plan) the shareholders of KSE-100 companies experienced an overall positive wealth effect, in dollar terms, cumulative over three days -2, $-1,0$, which was roughly 1.87 billion dollars (4\%). Whereas, during Event 3 (the Chinese President's visit to Pakistan to sign the CPEC agreement), the positive wealth impact on shareholders' wealth, cumulative over days $(-15,0)$ was roughly 5.58 billion dollars $(8.25 \%)$.

The CPEC agreement would be implemented in three phases: the early harvest, medium phase and the final phase, ending in year 2030. As work on these 46 billion dollar projects progress, the parties to this bilateral contract (China and Pakistan) could contemplate further enhancements of these agreements inviting other regional players into the fold such as, Iran, India, and the Central Asia states. In addition, the CPEC agreement is a subset of China's much larger "One Belt One Road" initiative. The results of our study would surely provide significant evidence on the value of these regional trade agreements and positive impact on OBOR initiatives. It is important to note that the South and Central Asian region is the least connected trade region of the globe.

The results of our study should be interpreted with caution. We were unable to provide a sector wise wealth impact of the CPEC agreement since firm-specific historical data was not available to us. In addition, the KSE-100 Index is primarily composed of the largest Pakistani firms; hence our results could have the large-firm effect bias.

\section{References}

A. P. (2016). Pak-China trade increases by $18.2 \mathrm{pc}$ to $\$ 4.4$ billion. Dawn News, April 27, 2016. Retrieved from https://www.dawn.com/news/1254586/pak-china-trade-increases-by-182pc-to-44-billion

Asian Infrastructure Investment Bank (AIIB). Retrieved from https://www.aiib.org/en/index.html

Cai, P. (2016). Why India is Wary of China's Silk Road Initiative. The Huffington Post, September 7, 2016. Retrieved from http://www.huffingtonpost.com/peter-cai/india-china-silk-road-initiative_b_11894038.html

Deloitte Survey. (2014-2015). How will CPEC boost Pakistan Economy? Retrieved from https://www2.deloitte.com/content/dam/Deloitte/pk/Documents/risk/pak-china-eco-corridor-deloittepk-noe xp.pdf

Ebrahim, Z. (2015). China's new silk road: What's in it for Pakistan? Dawn, April 20, 2015. Retrieved from https://www.dawn.com/news/1177116

Elkins, Z., Guzman, A., \& Simmons, B. (2006). Competing for Capital: The diffusion of bilateral investment treaties, 1960-2000. International Organization, 60(4), 811

Ghani, W., \& John, H. (1995). The Impact of the North American Free Trade Agreement on Multinational Firms: Evidence from the Stock market. Journal of International Accounting Auditing and Taxation, 4(2). https://doi.org/10.1016/1061-9518(95)90015-2

Ghani, W., \& John, H. (1998). Market Reaction of Multinational Corporations tPassage of the General 
Agreement on Tariffs and Trade (GATT). Journal of International Accounting, Auditing and Taxation, 7(1), 95-112. https://doi.org/10.1016/S1061-9518(98)90008-8

Haider, M., \& Haider, I. (2015). Economic Corridor is the Focus as Pakistan and China Signs 51 MoUs. Dawn News. April 20, 2015. Retrieved from http://www.dawn.com/news/1177109

Kaplan, R. (2010). Monsoon: The Indian Ocean and the Future of American Power. New York, NY: Random House.

Markey, D., \& West, J. (2016). Behind China's Gambit in Pakistan. Council on Foreign Relations. May 12, 2016. Retrieved from http://www.cfr.org/pakistan/behind-chinas-gambit-pakistan/p37855

Mehmood, K. (2013). Nawaz's Beijing visit: Trade corridor tops MoU bonanza. The Express Tribune. Retrieved from http://tribune.com.pk/story/573220/nawazs-beijing-visit-trade-corridor-tops-mou-bonanza/

N. A. (2013). Joint Statement - Deepening Comprehensive Strategic Cooperation between the People's Republic of China and the Islamic Republic of Pakistan. Ministry of Foreign Affairs - Government of Pakistan. May 25, 2013. Retrieved from http://www.mofa.gov.pk

N. A. (2016). Our bulldozers, our rules: China's foreign policy could reshape a good part of the world economy. The Economist, Beijing. July 2, 2016.

N. A. (n. d.). How will CPEC boost Pakistan economy? Deloitte. Retrieved from https://www2.deloitte.com/pk/en/pages/ccg/articles/how-will-cpec-boost-pakistan-economy.html

Naseem, A. (2015). Impact of China Pak Economic Corridor - A Bird's Eye View. BMA Capital, Pakistan. May 19, $2015 . \quad$ Retrieved from http://investorguide360.com/wp-content/uploads/2015/05/Impact-of-China-Pak-Economic-Corridor_-A-Bir ds-Eye-View.pdf

Reuters. (2013). Pak-China economic corridor to restore peace in region: Chinese PM. The Express Tribune. May 22, $2013 . \quad$ Retrieved from http://tribune.com.pk/story/552820/pak-china-economic-corridor-to-restore-peace-in-region-chinese-pm/

Scheraga, C., \& John, C. (1996). The Industry Effects of Information and Regulation in the Cigarette Market: 1950-1965. Journal of Public Policy \& Marketing, 15(2), 216-226. Retrieved from http://digitalcommons.fairfield.edu/business-facultypubs/109

Shah, S., \& Page, J. (2015). China Readies \$46 Billion for Pakistan Trade Route. The Wall Street Journal. April 16, $2015 . \quad$ Retrieved from http://www.wsj.com/articles/china-to-unveil-billions-of-dollars-in-pakistan-investment-1429214705

Singh, M. (2013). Li Keqiang Visit to Pakistan: Assessing the Outcome. IDSA. June 5, 2013. Retrieved from http://www.idsa.in/issuebrief/LiKeqiangVisittoPakistan_mandipsingh_050613\#footnote4_ywkrm5x

TNN. (2016). CPEC: Why Pakistan views corridor to China as a 'Game-changer'. The Economic Times. $\begin{array}{llll}\text { September } & 13, & 2016 . & \text { Retrieved }\end{array}$ http://economictimes.indiatimes.com/news/defence/cpec-why-pakistan-views-corridor-to-china-as-a-gamechanger/articleshow/54306105.cms

Vandevelde, K. J. (1998). Investment Liberalization and Economic Development: The Role of Bilateral Investment Treaties. Retrieved from http://heinonline.org/HOL/LandingPage?handle=hein.journals/cjtl36\&div=36\&id=\&page=

Vandewalle, L. (2015). Pakistan and China: 'Iron brothers' forever? European Parliament, Policy Department, Directorate-General for External Policies. June 18, 2015. Retrieved from http://www.europarl.europa.eu/RegData/etudes/IDAN/2015/549052/EXPO_IDA(201)549052_EN.pdf

Walsh, D. (2013). Chinese Company Will Run Strategic Pakistan Port. The New York Times. Retrieved from http://www.nytimes.com/2013/02/01/world/asia/chinese-firm-will-run-strategic-pakistani-port-at-gwadar.ht $\mathrm{ml}$ ?_r=0

\section{Copyrights}

Copyright for this article is retained by the author(s), with first publication rights granted to the journal.

This is an open-access article distributed under the terms and conditions of the Creative Commons Attribution license (http://creativecommons.org/licenses/by/4.0/). 